\title{
Sodium Valproate in the Treatment of Cerebellar Disorders
}

\author{
ANDREAS N.NEOPHYTIDES, PAUL F.TEYCHENNE, RONALD F. PFEIFFER, DONALD B.CALNE
}

SUMMARY: Because of the high concentrations of $\gamma$-aminobutyric acid $(G A B A)$ in the cerebellar cortex and nuclei, an attempt was made to enhance GABAergic transmission in patients with cerebellar disease. Maximum tolerated doses of sodium valproate, a drug which inhibits the degradation of $G A B A$, failed to influence cerebellar deficits in a double blind crossover study on six patients.

RESUME: A cause de la concentration élevée d'acide $\gamma$-aminobutyrique (GABA) dans le cortex et les noyaux cérébelleux, nous avons tenté de favoriser la transmission GABA ergique chez des patients souffrant de maladies de cervelet. Des doses maximales tolérables de valproate de sodium, un médicament qui inhibe la dégradation du $G A B A$, ont été incapables de modifier les déficits cérébelleux lors d'un étude à double-insu avec protocole d'inversion chez six patients.
From the Experimental Therapeutics Branch National Institute of Neurological and Communicative Disorders and Stroke, National Institutes of Health, Bethesda, Maryland 20014.

Reprint requests to Dr. D.B. Calne, Building 10 Room 6D20, National Institutes of Health, 9000 Rockville Pike, Bethesda, Maryland 20014, U.S.A.

\section{INTRODUCTION}

$\gamma$-Aminobutyric acid is a neurotransmitter distributed widely in the mammalian central nervous system (Roberts, 1974; Fahn and Cote, 1968; Perry et al., 1971; Okata, 1971). High levels of this compound have been demonstrated in the cerebellar cortex where it is contained in neurons comprising various local networks (Bisti et al., 1971; Hökfelt and Ljungdahl, 1975) and in the deep cerebellar nuclei, being located in the axon terminals of Purkinje neurons (Obata, 1976; Otsuka et al., 1971). Modulation of the afferent impulses takes place in the cerebellar cortex, the output of which is communicated through the firing of the Purkinje neurons to the deep cerebellar nuclei (Ito et al., 1970; Eccles et al., 1967) and from there to other circuits concerned with the integration of motor function. Symptoms of cerebellar dysfunction may then arise from dysfunction of GABAcontaining neural pathways and, conversely, pharmacologic manipulation of GABA mediated transvalue in the treatment of cerebellar disorders.

In order to investigate this hypothesis, we treated a group of patients manifesting systoms of cerebellar dysfunction with sodium valproate, a drug which elevates brain levels of GABA (Sawaya et al., 1975).

\section{MATERIALS AND METHODS}

Six patients (5 males, 1 female) participated in the study. Four were hospitalized throughout, while two were only admitted during part of the study. Five had multiple sclerosis (MS). The remaining patient had a slowly progressive cerebellar disorder, probably the result of chronic alcohol intake.

Symptoms of pyramidal involvement were also present in four of the MS patients. With the exception of phenytoin $200 \mathrm{mg} /$ day for the treatment of epilepsy in one of the MS patients, none was receiving other drugs.

A double blind crossover study was conducted in order to compare the effect of sodium valproate with that of an identically appearing placebo. A random order of administration of drug-placebo treatment was undertaken. Valproate was started at a dose of $200 \mathrm{mg}$ daily and increased by $100-$ $200 \mathrm{mg}$ every other day up to a maximum of $3000 \mathrm{mg} /$ day. In one patient, the dose was increased to 5600 $\mathrm{mg} /$ day for one week. Whenever side effects were encountered, the dose was temporarily decreased and a slower rate in dose increase was adopted. The mean duration of the active drug treatment was $40 \pm 4$ days (range 25-52) per patient, whereas that of maximum dose was $11 \pm 3$ days (range 5-22).

Neurologic function was evaluated by two independent observers twice a week. One observer conducted a clinical assessment of the following features: truncal ataxia; nystagmus; dysarthria; titubation; impairment of balance; difficulty with dressing, washing, and eating; reflexes; tremor; dysdiadochokinesis; dysmetria; hypotonia; and ability to place sequentially a fixed number of matches in a small glass. Dysfunction was rated on a scale of 0 (absent) to 4 (maximal).

The second blind observer evaluated incoordination in the upper extremities by means of an oscillometer which detected deviations from 3 motor tasks in which the patient 
attempted to execute precise movement of the hand along a set course.

Motion pictures were obtained during placebo and active drug treatment and were evaluated independently by three observers, who were unaware of the patients' therapy.

In order to detect any drug toxicity, routine hematologic and biochemical tests were performed at least twice weekly. Vital signs were recorded twice daily.

Since the usual anticonvulsant dose of sodium valproate is in the range of $1500 \mathrm{mg} /$ day, the treatment period was divided into a low dose (1200-1600 $\mathrm{mg} /$ day) and high dose (2800-5600 $\mathrm{mg} /$ day) phase. A summary of the pertinent clinical information on the patients studied is shown in Table 1.

Statistical comparisons were computed by means of the Student's t test for paired data between placebo and baseline, low dose, and high dose treatment periods, respectively.

\section{RESULTS}

There was no significant difference between the total scores recorded during baseline, placebo, low dose or high dose treatment periods (Fig. 1); a comparison of the individual clinical features that were measured also failed to reveal any significant change.

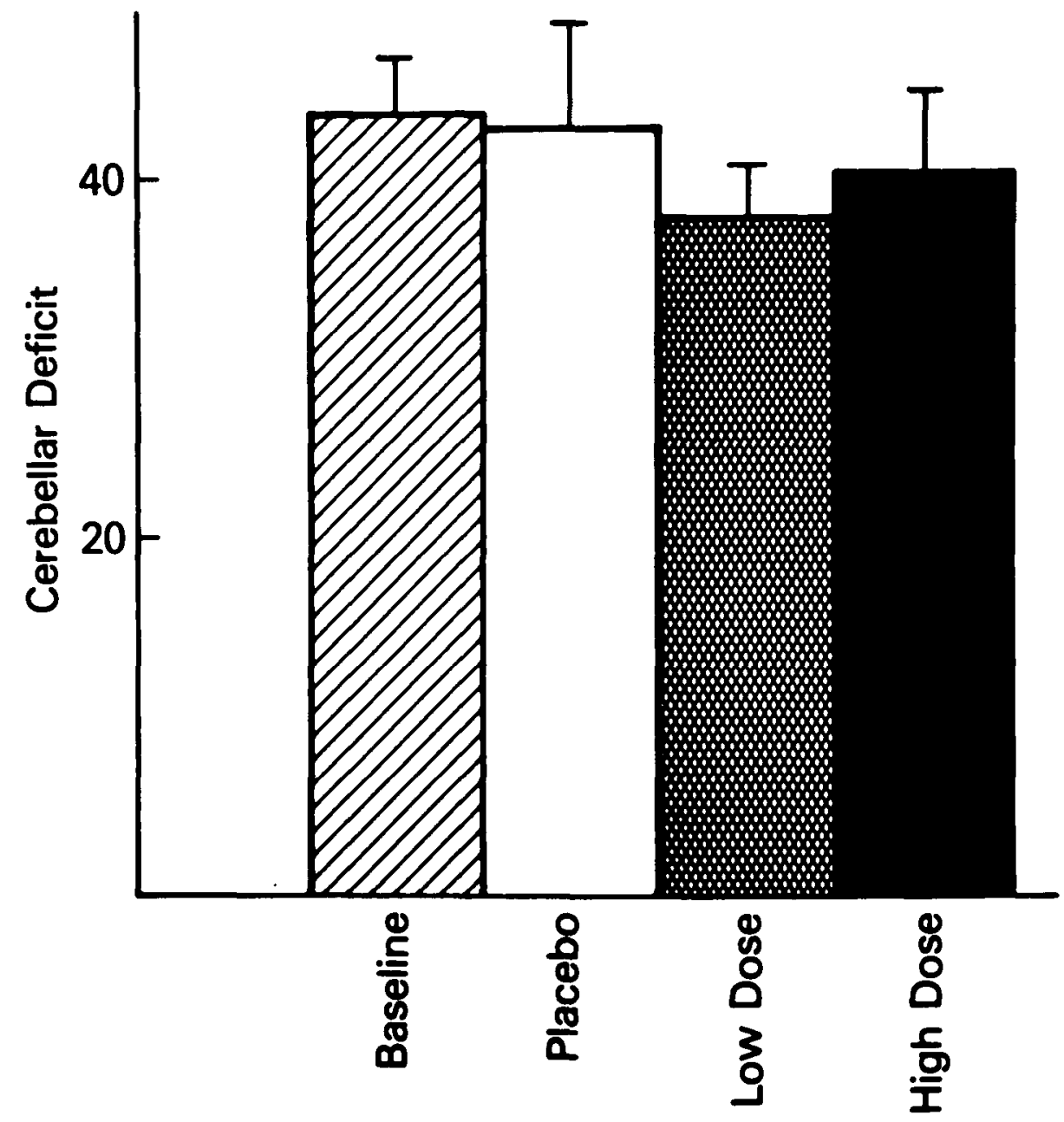

Figure 1 - Clinical scores of cerebellar dysfunction during baseline period, administration of placebo, low dose $(1200-1600 \mathrm{mg} /$ day, mean $1300 \mathrm{mg} /$ day $)$, or high dose $(2800-5600 \mathrm{mg} /$ day, mean $3390 \mathrm{mg} /$ day) of sodium valproate. There is no significant change with any treatment. (Student's $t$ test for paired data).

TABLE 1

Clinical Features

\begin{tabular}{cccccc}
\hline Patient & Diagnosis & $\begin{array}{c}\text { Severity of } \\
\text { Cerebellar } \\
\text { Dysfunction }\end{array}$ & $\begin{array}{c}\text { Other } \\
\text { Signs }\end{array}$ & $\begin{array}{c}\text { Maximum } \\
\text { Dose Valproate } \\
\mathbf{m g} / \mathbf{k g} / \text { day }\end{array}$ & $\begin{array}{c}\text { Adverse } \\
\text { Effects }\end{array}$ \\
\hline 1 & MS & Severe & & 55 & $\begin{array}{c}\text { Sedation } \\
\text { Nausea }\end{array}$ \\
2 & MS & Moderate & Pyr, Sens & 53 & Sedation \\
3 & MS & Severe & Pyr, Sens & 60 & Thrombocytopenia \\
4 & MS & Moderate & Pyr & 53 & $\begin{array}{c}\text { Nausea } \\
\text { Sedation } \\
5\end{array}$ \\
& MS & Mild & Pyr, Sens, I.O. & 31 & None \\
6 & ACD & Moderate & - & 39 & None \\
\hline
\end{tabular}

MS = Multiple Sclerosis

$\mathrm{ACD}=$ Alcoholic Cerebellar Degeneration

Pyr = Pyramidal

1.O. = Internuclear Ophthalmoplegia

Sens $=$ Sensory Deficit 
Similarly, the oscillometric recordings and the blind review of the motion pictures did not demonstrate any significant difference.

Two patients developed nausea which responded to temporary reduction of the drug dose. In a second patient, the platelet count decreased to $60,000 / \mathrm{mm}^{3}$ during treatment with high doses of sodium valproate. No evidence of bleeding diathesis was apparent and platelets returned to normal after discontinuing the drug. Sedation was encountered in three patients; this was mild and did not necessitate a dose reduction.

After the conclusion of the study, patient No. I was placed on clonazepam $0.5 \mathrm{mg}$ t.i.d. and the dose was slowly increased to a total of $16 \mathrm{mg}$ daily in five divided doses. A beneficial response was seen with as low as six $\mathrm{mg}$ of clonazepam and a significant improvement was observed at $16 \mathrm{mg}$. $\mathrm{He}$ was able to walk more freely; speech was clearer; and he was able to perform tasks such as holding a cup, playing golf and writing. He has now received clonazepam for 18 months, with a sustained therapeutic effect.

\section{DISCUSSION}

Several possibilities may account for the failure of sodium valproate to influence the cerebellar symptomatology of the above patients. The doses administered in this study, although considerable higher than those employed for the treatment of epilepsy, may not be sufficient to elevate GABA levels. The doses of valproate needed to increase the brain concentration of GABA in the laboratory animal are higher than those employed in humans (Sawaya et al., 1975). In this context, drugs that stimulate the GABA receptor, such as the presumed GABA agonist muscimol, may be of interest.

Enhancement of GABA-mediated transmission at specific synapses rather than indiscriminate elevation of GABA in the cerebellum may be needed to influence motor function. However, such precise neurochemical manipulation is not currently attainable.

It is possible that the pathology in these patients involves quantitative or qualitative changes in GABA receptors. Methods are available to detect such changes (Enna et al., 1976), but to our knowledge have not been carried out in patients with cerebellar disorders.

Further therapeutic trials with more potent GABAergic agents will be needed to elucidate the role, if any, of this neurotransmitter in the production of symptoms of cerebellar dysfunction.

\section{ACKNOWLEDGEMENT}

We wish to thank lan Walters for building the apparatus employed to measure oscillations during movement.

\section{REFERENCES}

BISTI, S., IOSIF, G., MARCHESI, G.F., and STRATA, P. (1971). Pharmacological properties of inhibitions in cerebellar cortex. Exp. Brain Res., 14, 24-37.
ECCLES, J., ITO, N., and SZENTAGOTHAI, J. (1967). The Cerebellum as a Neuronal Machine. Springer: Berlin.

ENNA, S.J., BIRD, E. D., BENNET, J.P., et al. (1976). Huntington's Chorea. Changes in neurotransmitter receptors in the brain. N. Eng. J. Med., 295, 1305-1309.

FAHN, S. and COTE, L.J. (1968). Regional distribution of gamma-aminobutyric acid (GABA) in brain of Rhesus monkey. J. Neurochem., 15, 209-213.

HOKFELT, T., and LJUNGDAHL, A. (1975). Cerebral localization of labeled $\boldsymbol{\gamma}$-aminobutyric acid $\left({ }^{3} \mathrm{H}\right)$ - GABA in rat cerebellar cortex: an autoradiographic study. Brain Res., 88:295-308.

ITO, M., YOSHIDA, M., OBATA, K., et al. (1970). Inhibitory control of intracerebellar nuclei by the Purkinje cell axons. Exp. Brain Res., 10, 64-80.

OBATA, K. (1976). Association of GABA with cerebellar Purkinje cells: single cell analysis. In GABA in Nervous System Function, edited by E. Roberts, T.N. Chase, and D. B. Tower, pp. 217-222. Raven Press: New York.

OKATA, Y., NITCH-HASSLER, C., KIM, S.S., et al. (1971). Role of $\gamma$-aminobutyric acid (GABA) in the extrapyramidal motor system. 1. Regional distribution of GABA in rabbit, rat, guinea pig and baboon CNS. Exp. Brain Res., 13. 514.

OTSUKA, M., OBATA, K., MIYATA, Y., and TANAKA, Y. (1971). Measurement of $\gamma$-aminobutyric acid in isolated nerve cells of cat central nervous system. J. Neurochem., 18, 287-295.

PERRY, T. L., BERRY, K., HANSEN, S., et al. (1971). Regional distribution of amino acids in human brain obtained at autopsy. J. Neurochem., 18, 513-519.

ROBERTS, E. (1974). $\gamma$-Aminobutyric acid and nervous system function - $A$ perspective. Biochem. Pharmacol.. 23, 2037-2049.

SAWAYA, M.C.B., HORTON, R.W, and MELDRUM, B.S. (1975). Effects of anticonvulsant drugs on the cerebral enzymes metabolizing GABA. Epilepsia, 16, 549-573. 